\title{
SROVNÁNÍ POPISU BUDDHISTICKÝCH OSMI VĚDOMÍ SE STRUKTUROU MOZKU U ČLOVĚKA
}

\author{
11: $1-270,2009$ \\ ISSN 1212-4117 \\ Petr Zach¹, Jana Mrzílkováa , Stanislava Kučováa
}

${ }^{1}$ Jihočeská univerzita v Českých Budějovicích, Zdravotně sociální fakulta, katedra preklinických oborů

2 Karlova univerzita v Praze, Anatomický ústav, 3. lékařská fakulta

${ }^{3}$ Karlova univerzita v Praze, Filozofická fakulta

\section{ÚVOD}

Jakým zpo̊sobem dochází k utváření reakce člověka na př́tomnou situaci? Co je podkladem pro každodenní chování a jednání v konkrétních situacích? Máme možnost to ovlivnit, nebo ne? Tyto a podobné základní otázky člověka je možno s přibývajícími znalostmi na poli neurověd a buddhismu - tzv. neurobuddhismu zodpovědět způsobem, který byl ještě před několika lety nemyslitelný. Máme totiž $\mathrm{k}$ dispozici velké množství dat a informací z obou stran ze západní vědecké tradice, vědeckého myšlení a vědy a výzkumu a $z$ druhé strany $z$ kontemplativních introspektivních metod vhledů do vědomí jednotlivce. Syntéza informací z těchto disciplín má podle nás potenciál přirovnatelný ke změně paradigmatu od klasické newtonovské fyziky ke kvantové mechanice. Samotný neurovědný popis struktury mozku nedává odpověd' na subjektivní prožitkovou část zkušenosti reality, která má navíc individuální charakter. $\mathrm{Na}$ druhou stranu neumožňuje introspektivní (kontemplativnî) dovednost jednotlivce většinou předání takovéto zkušenosti okolí, což je zřejmě důvodem pro nesnadný pokrok na tomto poli z hlediska veřejnosti. Naše práce je jednou z prvních, pokoušející se o syntézu terminologické roviny mezi neurovědným popisem CNS a buddhistickým popisem funkce vědomí.

\section{METODA}

Buddhistické učení o př́činné souvislosti, madhyamaka, zvláště část zabývající se popisem osmi vědomí (pět senzorických vědomí - zrakové, čichové, sluchové, chut'ové a dotyku, šesté vědomí - mentální, sedmé vědomí - zatemňují- cí, osmé vědomí [alaya vijnana] - sklad, pamět'), má řadu prvků připomínajích základní neuroanatomické rozdělení struktury mozku. Náš pokus o takovéto srovnání záměrně ignoruje komplikovanost a rozdíly $\mathrm{v}$ popisu osmi vědomí v tradiční buddhistické literatuře a sútrové tradice různých buddhistických škol (yogacara, svatantrika, prasanghika, cittamatra apod.). Mezi odbornou veřejností roste zájem o komunikaci mezi meditátory buddhistické tradice a západními špičkovými vědci na úrovni mnoha disciplín a oborů, viz např. organizaci Mind and Life Institute (www.mindandlife.org) založenou Franciskem Varelou a 14. dalajlamou v roce 1987. Jádro našeho srovnání obou přístupů je vyjádřeno slovy „zatímco západní věda za pomoci technologií (mikroskopy, dalekohledy apod.) popsala strukturu a procesy mozku, buddhistický př́stup založený na introspekci meditační praxi (shamata, vipassana) dospěl $\mathrm{z}$ fenomenologického hlediska $\mathrm{k}$ podobnému popisu, avšak nikoliv $\mathrm{v}$ termínech struktury a funkce mozku, ale funkce mysli“" (Wallace, 1999). Buddhistická doktrína nikdy nepracovala se strukturou mozku, a tak v ní není ani náznak, že by mozek vytvářel nebo byl zdrojem vědomí (mysli) - s tím prícházejí až moderní neurovědy a biologická psychiatrie. Z buddhistického hlediska je nepodstatné uvažovat o struktuře a funkci mozku, pokud jde o pochopení fungování vědomí (mysli). Důležitým aspektem buddhistického vysvětlení uspořádání a funkce mysli je jeho využití v meditační praxi - celek má pak spíše charakter soteriologický než filozofický. Popis fungování mysli v buddhismu je ale natolik komplikovaný a přesný, že neaspiru- 
jeme na srovnání všech jeho aspektů, ale pouze vybraných částí, s popisem struktury a funkce mozku. Zajímá nás spíše možné překrytí etymologické (terminologické), označující podobné věci nebo jevy (jako jsou např. osmé vědomí buddhismu a koncept paměti).

\section{VÝSLEDKY}

Dhatu - plural dhatus - existuje různá kategorizace osmnácti dhatus (poznatelných věcî) na šest senzorických objektů, šest senzorických schopností (vloh) a šest vědomí (bez sedmého a osmého) vztahujících se $\mathrm{k}$ oku, uchu, nosu, jazyku a dotyku jako $\mathrm{k}$ anatomickým senzorickým orgánům (oko, ucho, nos, jazyk, nervová senzorická zakončení pohybového a kožního systému). Odpovídající vědomí př́slušného dhatu by pak korelovalo s funkčními korovými oblastmi mozku - oko a jeho vědomí zraku korové oblasti 17,18 , ucho a jeho vědomí zvuku (slyšenî) korové oblasti 41, 42. Jazyk (chut'ové) dhatu by mohlo odpovídat korové oblasti 28 a dhatu dotyku korové oblasti 3, 1, 2. Tímto způsobem bychom přidružili prvých pět vědomí buddhismu, zabývajících se senzorickými modalitami a odpovídajícími senzorickými orgány. Odtud jsou informace vedeny k funkčním korovými oblastem mozku, které by v buddhismu odpovídaly jednotlivým vědomím smyslů. Jejich vzájemné propojení vytvářející proces vidění, slyšení apod. je označován jako „co-dependent arising of phenomena - závislé povstávání jevư“ (Waldron, 2000). Aby se např. odehrál proces vidění, musí být splněny alespoň tři podmínky - existence pozorovaného objektu, senzorického orgánu a prríslušné korové oblasti mozku. Pokud jeden $\mathrm{z}$ těchto prvků chybí, proces se neodehraje. $V$ českém jazyce není př́tomna kvalita vidění, slyšení, čichání jako procesu, protože užíváme vyjádření z pohledu prvé osoby - „já vidím“ nebo „já slyším“. To je podle nás velice zavádějící, protože v celém procesu se nenachází centrální jednotka. Spíše jednotlivé komponenty procesu se účastní průběhu vidění nebo slyšení a předávají je dál ke zpracování jiným částem mozku (např. zraková informace odbočkou do hypotalamických jader pro nastavení autonomního nervového systému, na spodinu 4. komory mozku $\mathrm{k}$ jádru desátého hlavového nervu - nausea apod.). Jakýkoliv pokus o umístění pozorovatele $\mathrm{v}$ prrípadě procesu vidění do oční koule nebo do zrakové korové oblasti vyvolává dojem centrálního př́jemce informace, který není. Vyjádření „já vidím“ snadno vyvolává např̀. představu, že „já“ se nachází ve zrakové korové oblasti, na kterou se promítá optická informace prostřednictvím zrakové dráhy. Pokud se podíváme na možnost existence ,jác ve zrakové kưre, nenalezneme je. Podobně je tomu i v př́padě ostatních senzorických korových oblastí. "Ja" není př́tomno ani v mozku, oku, v našem těle, stejně jako v pozorovaném objektu či v prostoru mezi pozorovaným objektem a tělem. Je spíše prrítomno v situaci, jako kombinace všech zúčastněných komponent procesu (pozorovaný objekt, oko, zraková dráha a zraková korová oblast). To je z hlediska běžného života důležitý závěr. Automaticky ale přisuzujeme vlastnosti jevům nebo objektům, které je $z$ výše uvedeného nemohou obsahovat.

Koncept šestého vědomí pracuje s rozdělením na zevní a vnitřní aspekt. V buddhismu je popisován šestý percepční orgán (pro který nemáme morfologicky protějšek), který není podobný pěti předchozím smyslovým orgánům a který je ve vztahu $\mathrm{k}$ šestému vědomí. Podle buddhistické doktríny se mezi šestým smyslovým orgánem a šestým vědomím odehrává nepřetržitý tok informací. Šesté vědomí dostává informace z pěti senzorických vědomí a zároveň prostřednictvím sedmého vědomí získává informace z vědomí osmého (paměti, skladu). Informace uložené v alaya vijnana (pamět') jsou do šestého vědomí částečně chaotickým způsobem ale také jejich intenzitou a silou vyvolávány a dochází k jejich míchání s obsahy pěti senzorických vědomí. Asociační oblasti mozkové kůry propojují funkční korové oblasti prostřednictvím asociačních spojů (např. fasciculus longitudinalis telencephali) a mohly by terminologicky odpovídat šestému vědomí (mentálnímu), majícímu mimo jiné vlastnost „switch-board“ pro ostatních pět senzorických vědomí (Trungpa, 1991). Na úrovni šestého vědomí pozorujeme fenomén synestézie - neadekvátní vybavování nebo spojování sensorických vjemů, např. kombinace zrakového vjemu písmen nebo číslic s akustickými vjemy. V některých př́padech může docházet $\mathrm{k}$ vjemovým novotvarům, nedávajícím smysl. Z hlediska osmi vědomí dochází $\mathrm{k}$ tomuto spřažení senzorických vjemů na úrovni šestého vědomí s pomocí sedmého 
a osmého vědomí. V souladu s přiřazením asociačních korových oblastí šestému vědomí je vysvětlení synestézie poruchou konektivity nebo abnormálními neuronálními spoji na úrovni asociačních korových oblastí frontálního, parietálního, temporálního a okcipitálního laloku. Podle buddhistické teorie mysli pak porucha aspektu šestého vědomí yid - centrální složky koordinující senzorické zážitky do smysluplného celku (Trungpa, 1991).

Výklad sedmého vědomí (klesha's mind) buddhismu je komplikovanější, protože souvisí s emocemi a mentálními stavy. Částečně bychom jej mohli spojit s limbickým systémem, frontální a prefrontální kůrou a pamětí. Po probuzení ze spánku je často krátkou chvíli pocit klidu a prázdnoty, po které pamět'ové okruhy (s hipokampem) vybavují nahodilé sekvence minulých nebo budoucích událostí (vzpomínka na minulý den, plánování současného dne) a roli $\mathrm{v}$ tomto procesu hraje limbický systém a retikulární formace (bdělost, spánek). Sedmé vědomí nemá orgán percepce. Anatomickým protějškem by byly spoje mezi limbickým systémem, pamětí a prefrontální kůrou.

Osmé vědomí, alaya vijnana, je vědomí, kde jsou uloženy otisky všech akcí a činů, dávající vznikat dalším událostem a konsekvencím. Během našeho života nemáme $\mathrm{k}$ těmto informacím prrímý prrístup. Mohli bychom osmé vědomí pokládat za pamět' ale $\mathrm{v}$ mnohem širším významu než obvykle. Šlo by pak nejenom o korové oblasti mozku, nespecificky uchovávající informace prostřednictvím hipokampu ve spánkovém laloku. Osmé vědomí je mnohem širší termín/pole než ostatní vědomí a těžko je i přibližně porovnávat $\mathrm{k}$ popisu částí nebo i celku mozku.

\section{ZÁVĚR}

Je zřejmé, že strukturální popis mozku není dostačující k pokrytí všech oblastí buddhistické fenomenologie, a naopak. Již z principu popis mozku je metodologicky jiný než introspektivní náhled mysli. Nicméně považujeme za inspirativní nalezení možných korelací mezi oběma popisy vycházejícími z naprosto odlišné kultury.

Podle našeho chápání obou popisů (neurovědného a buddhistického) dochází ve vědomí $\mathrm{k}$ následujícím procesům, majícím základní význam pro chování člověka:

Pět senzorických vědomí vytváří „odrazy“ smyslových podnětů formou tvorby smyslových vědomí. Zároveň část vědomí „vytahuje“ z paměti obsahy, které se „míchaji““ $\mathrm{s}$ informacemi z pěti smyslových vědomí za asistence šestého vědomí nebo asociačních oblastí kůry a dalších struktur CNS. Takto se vytváří „,směs“ z paměti a smyslových vjemů. Možné důsledky a implikace:

a) výše popsaný proces probíhá neustále a člověk nemá možnost (s výjimkou patologických nebo extrémních situací) jeho charakter měnit;

b) lidé nejsou vychováváni a vedeni $\mathrm{k}$ uvědomění, že jejich současný stav mysli nebo těla je výsledkem této kombinace paměti a senzorických vstupů do CNS, takže

c) pokládají obrazy, které šesté vědomí „vytahuje“ z paměti (obecně paměti těla, procedurální a behaviorální paměti), za reálně existující mimo ně, v „zevním“ prostředí a následkem toho

d) reaguij činností na obsah své vlastní paměti spíše než na aktuální situaci ve svém okolí.

Oba koncepty - osm vědomí buddhismu a morfologický popis mozku - se v určitých bodech překrývají a dotýkají. Mozek a mysl spolu jistě souvisí, ale do jaké míry a na jaké úrovni ještě zbývá objevit. Přehled osmi vědomí Yogacary a neuroanatomická kolokalizace viz schéma č. 1. 


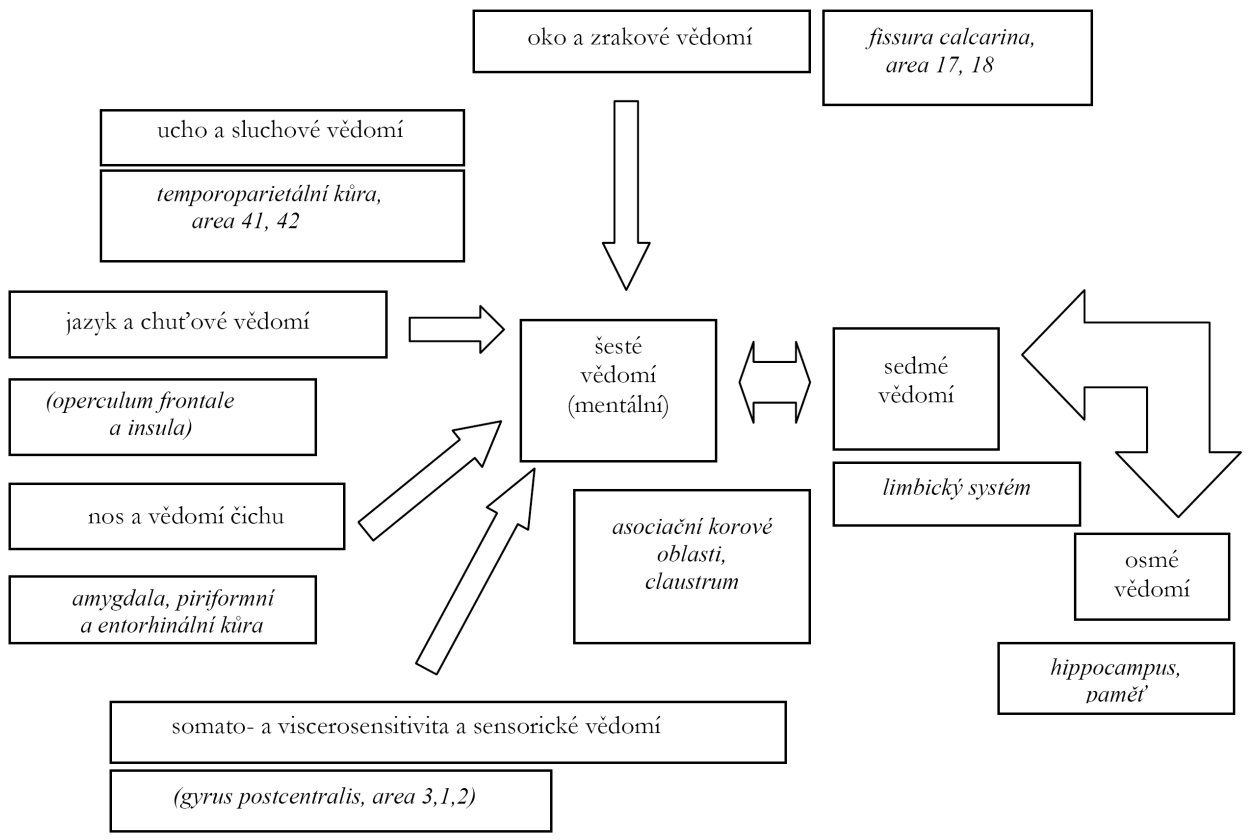

Rovným písmem je uveden buddhistický popis osmi vědomí a kurzivou odpovídající neuroanatomické termíny.

Zatímco standardní buddhismus popisuje pouze šest vědomí, buddhistická škola Yogacara (a její prístup cittamatra - „mysl pouze“) pracuje s osmi úrovněmi vědomí. Prvých pět vědomí jsou vědomí smyslová, vědomí smyslových orgánů. Jsou vytvářena prostřednictvín smyslů zraku, sluchu, čichu, chuti a somato a viscerosenzitivitou. Smyslová vědomí povstávají kontaktem mezi specifickým smyslovým orgánem a odpovídajícím smyslovým objektem. Např. kontaktem světelného paprsku s oční sítnicí (za současné existence všech prvků nutných pro uskutečnění procesu viděnî) se vytváří zrakové vědomí. Smyslová vědomí jsou tedy závislá na smyslových podnětech. Další vědomí - šesté - je úzce propojeno s funkcí pěti smyslových vědomí. Zatímco povstávání pěti smyslových vědomí je závislé na přítomnosti odpovídajících fyzikálních podnětů, šesté vědomí je vědomí mentální (mano-vijnana). Je to vědomí zahrnující myšlení, schopné induktivní a deduktivní argumentace a spojující informace z pěti smyslových vědomí do významového celku. Sedmé vědomí, nazývané vědomí „mysli“, je spojeno se šestým vědomím. Jevy z šestého vědomí se „míchaji““ se sedmým vědomím, které se zároveň „dívá“ na obsahy osmého vědomí a považuje je za permanentní „self - já““. Všech sedm vědomí připravuje a účastní se ukládání informací (buddhistický termín karma - systém propojení jakékoliv příčiny a následku teoreticky vysvětlitelným způsobem, ale prakticky nevysledovatelný ve všech souvislostech) do osmého vědomí (imprinty). Sedmé vědomí si zároveň tyto imprinty „prohlíži“ a prířazuje je jako významy nekonceptuálním informacím $\mathrm{z}$ pěti smyslových vědomí uvnitř vědomí šestého. $\mathrm{V}$ osmém vědomí se ukládají vzorce, imprinty, obsahy, odrazy našich akcí, činností a konání úplně a bez výjimky. Výsledkem tohoto neustále probíhajícího procesu jsou mentálně emoční komplexy, mající charakter konglomerátu paměti 
a odrazu pŕítomné situace na úrovni smyslových vjemů. Co je podstatné - tomuto směšování předchozích konstruktů pamět'ové stopy $s$ relativně nově vznikajícími smyslovými vědomími (představující nekonceptuální část informace) nelze bez technik $\mathrm{k}$ tomu určených zamezit. Z výše uvedeného jasně vyplývá, že jakýkoliv pokus o „nestranný nebo nezaujatý“ náhled, popis, reflexi, sdělení apod. je vždy „kontaminován“ a má vždy charakter tvoření ve smyslu uměleckého díla spíše než „objektivní“ skutečnosti.

\section{LITERATURA}

AUSTIN, J. H.: Zen and the brain. Cambridge, MA: MIT Press, 1999.

BENSON, H. et al.: Three case reports of the metabolic and electroencephalographic changes during advanced Buddhist meditation techniques. In: Behavioral Medicine, 1990, no 16, s. 90-95.

BROWN, D. et al.: Differences in visual sensitivity among mindfulness meditators and non-meditators. In: Perceptual and Motor Skills, 1984, no 58, s. 727-733.
DAVIDSON, R. J. et al.: Alternations in brain and immune function produced by mindfulness meditation. In: Psychosomatic Medicine, 2003, no 65, s. 564-570.

KELLY, B. D.: Buddhist Psychology, Psychotherapy and the Brain: A Critical Introduction. In: Transcultural Psychiatry, 2008, no 45, s. 5.

NEWBERG, A. B. et al.: The measurement of regional cerebral blood flow during the komplex cognitive task of meditation: A preliminary SPECT study. In: Psychiatry Research, 2001, no 106, s. 113-122.

TRUNGPA, C.: The Heart Of The Buddha. London: Shambhala, Boston, 1991.

WALDRON, W.: Beyond Nature/Nurture: Buddhism and Biology on Interdependence. In: Contemporary Buddhism, 2000. Vol. 1., no 2, s. 199-226.

WALLACE, B. A.: The Buddhist tradition of Samatha: Methods for refining and examining consciousness. In: Journal of Consciousness Studies, 1999. Vol. 6, no 2-3, s. $175-187$.

* Tato práce byla podpořena grantem FRVŠ 425/2007 a IGA 9180-3 a je součástí aktivit předmétu Práce se stresem na ZSF JU.

Petr Zach et al. zach.petr@post.cz 